\title{
Pengaruh pemberian antibiotik terhadap tanda infeksi daerah operasi superfisial dan lama tinggal pasien sectio caesaria
}

\author{
Teulis Sumiartini ${ }^{1}$, Dian Ratih Laksmitawati ${ }^{1}$, Hesti Utami Ramadaniati ${ }^{1}$, \\ Ronald Irwanto Natadidjaja ${ }^{2,3}$, Rudi Asmajaya ${ }^{3}$
}

\begin{abstract}
ABSTRAK
\section{LATAR BELAKANG}

Standar Nasional Akreditasi Rumah Sakit (SNARS) edisi 1/2018 menjadikan kejadian Infeksi Daerah Operasi (IDO) sebagai salah satu indikator mutu untuk menilai kinerja pengendalian infeksi di rumah sakit. Pemberian antibiotik lanjutan pascaoperasi sectio caesaria (SC) menjadi isu yang penting untuk dikaji, mengingat operasi ini pada dasarnya tidak membutuhkan pemberian antibiotik lanjut pascaoperasinya. Penelitian ini bertujuan untuk melihat apakah pemberian antibiotik lanjutan pascaoperasi SC berpengaruh terhadap penurunan IDO superfisial dan Length of Stay (LOS) pasien.

\section{METODE}

Pasien dibagi menjadi 2 kelompok dengan jumlah masing-masing sebesar 49 subjek. Kelompok pertama adalah kelompok subjek yang diberikan antibiotik lanjut pascaoperasi SC dan kelompok kedua adalah kelompok subjek yang tidak diberikan antibiotik lanjutan pascaoperasi SC, kemudian dari masing-masing kelompok dikaji kemungkinan munculnya tanda IDO superfisial dan LOS pasien. Desain penelitian ini adalah kohort retrospektif dengan data sekunder dari rekam medis pasien Januari 2019-Desember 2019. Uji analisa dengan Chi-square.
\end{abstract}

\section{HASIL}

Setelah mengontrol variabel perancu, pemberian antibiotik lanjut pascaoperasi $\mathrm{SC}$ tidak signifikan berpengaruh menurunkan kemungkinan munculnya tanda IDO superfisial $(\mathrm{OR}=0.157 ; \mathrm{p}=0.098 ; 0.02-1.41 \mathrm{IK}$ $95 \%)$, juga tidak memiliki pengaruh terhadap $\operatorname{LOS}$ pasien $(\mathrm{OR}=1.73$; $\mathrm{p}=0.562 ; 0.27-10.85$ IK 95\%).

\section{KESIMPULAN}

Tidak terdapat pengaruh dari pemberian antibiotik lanjutan terhadap tanda kejadian IDO superfisial dan LOS pada pasien post SC. Pemberian antibiotik lanjutan pascaoperasi SC merupakan pemberian antibiotik yang tidak bijak.

Kata kunci: antibiotik, sectio caesaria, infeksi daerah operasi, IDO, length of stay, LOS
${ }^{1}$ Magister Farmasi, Fakultas

Farmasi Universitas Pancasila, Indonesia

2 Departemen Ilmu Penyakit Dalam, Fakultas Kedokteran Universitas Trisakti, Indonesia

${ }^{3}$ Yayasan Pelita RASPRO

Indonesia

\section{Korespondensi:}

Teulis Sumiartini

Magister Farmasi, Fakultas Farmasi Universitas Pancasila, Indonesia Jalan Raya Lenteng Agung Srengseng Sawah, Jagakarsa, Kota Jakarta Selatan, 12630, Indonesia Email:

teulis.arafah@gmail.com

J Biomedika Kesehat 2021;4(1):5-11 DOI: $10.18051 /$ JBiomedKes.2021. v4.5-11

pISSN: 2621-539X / eISSN: 2621-5470

Artikel akses terbuka (open access) ini didistribusikan di bawah lisensi Creative Commons Attribution 4.0 International (CC-BY 4.0) 


\section{ABSTRACT}

\section{Effect of continuing antibiotics on the event of superficial surgical site infection and length of stay of patients with cesarean section}

\section{BACKGROUND}

The National Hospital Accreditation Standard (SNARS) edition 1/2018 defined the Surgical Site Infection (SSI) as one of the quality indicators to assess infection control performance in hospitals. Postoperative antibiotic administration is an important issue to be reviewed. Basically, SC does not require postoperative antibiotics. Postoperative antibiotics after SC surgery categorized as an antibiotic overuse. This study aims to determine whether the administration of post-SC follow-up antibiotics has an effect on reducing superficial SSI and patient Length of Stay (LOS).

\section{METHODS}

Patients were divided into 2 groups with a total of 49 subjects each. The first group was a group of subjects who were administered postoperative antibiotic in SC and the second group was a group of subjects with no postoperative antibiotics in SC. Then, from each group the possibility of the appearance of signs of Superficial SSI and LOS was compared. Design of this study is a retrospective cohort with secondary data from patient medical records January 2019 - December 2019. Data were analyzed with Chi-square.

\section{RESULTS}

After confounding variables controlled, postoperative antibiotic in SC had no significant effect on reducing the likelihood of Superficial SSI symptoms (OR=0.157; $\mathrm{p}=0.098 ; 0.02-1.41 \mathrm{IK} 95 \%)$, also had no effect on patient $\operatorname{LOS}(\mathrm{OR}=1.73 ; \mathrm{p}=0.562 ; 0.27-10.8595 \% \mathrm{CI})$.

\section{CONCLUSION}

There was no effect of postoperative antibiotic in reducing symptoms of Superficial SSI and LOS in post-SC patients. Postoperative antibiotic in SC is not prudent use of antibiotic.

Keywords: antibiotic, sectio caesaria, surgical site infection, SSI, length of stay, LOS

\section{PENDAHULUAN}

Komplikasi infeksi yang dapat terjadi setelah operasi sectio caesaria (SC) merupakan penyebab morbiditas yang penting yang mungkin bisa menimbulkan biaya kesehatan yang tinggi. Tindakan SC sebenarnya merupakan salah satu tindakan operasi yang tergolong bersihterkontaminasi (clean-contaminated), dan pemberian antibiotik profilaksis bedah sangat direkomendasikan. Prinsip umum menyatakan bahwa pemberian antibiotik profilaksis tidak dilanjutkan pascaoperasi.

Pada kasus-kasus operasi, antibiotik profilaksis yang tidak rasional adalah apabila antibiotik digunakan spektrum luas dan digunakan sebagai terapi lanjutan tanpa rekomendasi periode waktu. Sementara pada operasi SC juga kerap pemberian antibiotik profilaksis diperpanjang.(1) Penelitian lain di sebuah rumah sakit di Jakarta menunjukkan bahwa $84.68 \%$ pasien menerima pemberian antibiotik tidak tepat waktu dan $81.89 \%$ pasien menerima antibiotik profilaksis pada $>24$ jam..$^{(2)}$ Di mana hal ini berarti masih terjadi perpanjangan waktu pemberian antibiotik yang dilanjutkan pascaoperasi. Sementara itu, sebuah penelitian di sebuah rumah sakit di Indonesia mendapatkan bahwa pemberian antibiotik lanjutan pada sampel subjek dengan SC masih dilakukan dengan berbagai alasan di dalamnya. ${ }^{(3)}$ Natadidjaja et al mengungkapkan bahwa sebagian besar rumah sakit yang menyatakan belum menjalankan program pengendalian resistensi antimikroba membutuhkan konsep pelaksanaan yang jelas dalam penggunaan antibiotik bijak. ${ }^{(4)}$

Konsep pelaksanaan penggunaan antibiotik bijak juga harus mencakup penggunaan antibiotik pada berbagai jenis operasi, termasuk operasi SC yang tergolong sebagai clean-contaminated. Pada konteks ini, penggunaan antibiotik tidak dilanjutkan pascaoperasi. Secara prinsip, penggunaan antibiotik pada operasi tergolong clean-contaminated harus mudah, singkat, diberikan 30-60 menit sebelum operasi dan pemberiannya tidak berkelanjutan pascaoperasi. $(5,6)$ Antibiotik yang diberikan dengan cara demikian bertujuan untuk mengurangi jumlah koloni bakteri, mengurangi jumlah inokulum kontaminasi sehingga menurunkan risiko infeksi. Penelitian ini bertujuan untuk melihat apakah pemberian antibiotik lanjutan pascaoperasi SC berpengaruh terhadap penurunan IDO superfisial dan Length of Stay (LOS) pasien. 


\section{METODE}

Desain penelitian ini adalah kohort retrospektif dengan data sekunder dari rekam medik pasien yang beriwayat SC di sebuah rumah sakit dari bulan Januari hingga Desember 2019. Sampel uji diambil dari data rekam medik pasien melalui Hospital Information System (HIS) dengan menggunakan rumus perbedaan 2 proporsi. Subjek dibagi kedalam 2 kelompok dengan masingmasing kelompok berjumlah 49 subjek penelitian. Kelompok pertama adalah kelompok subjek yang mendapatkan antibiotik lanjutan pascaoperasi SC, baik oral ataupun injeksi. Kelompok kedua adalah kelompok subjek yang tidak mendapatkan antibiotik lanjutan pascaoperasi SC. Data dianalisa secara bivariat dengan menggunakan Chi-square. Analisa perancu secara multivariat dengan melihat hubungan antara masing-masing variabel perancu dengan kejadian IDO superfisial dan LOS. Kriteria eksklusi adalah pasien dengan pasca-SC dengan HIV, pasien pasca-SC yang memutuskan pulang atas permintaan sendiri, pasien pascaoperasi SC dari rumah sakit lain dengan tanda kejadian IDO, pasien pasca-SC dengan diagnosis infeksi lain. Setelah diambil sampel sesuai rumus, pasien dibagi menjadi 2 kelompok.

IDO superfisial dikategorikan sesuai ketentuan umum dari Center of Disease Control (CDC), yaitu infeksi yang terjadi dalam 30 hari setelah prosedur operasi yang hanya melibatkan kulit atau jaringan subkutan dari insisi saat di rawat pascarawat kontrol ke-1 (hari ke-3 sd. hari ke-10). Kontrol ke-2 pasca rawat (hari ke-11 sd. hari ke-30). ${ }^{(7,8)}$ Lama perawatan/Length of Stay (LOS) sebuah istilah yang didefinisikan sebagai periode waktu pasien dirawat di rumah sakit dihitung dari hari masuk sampai hari pasien keluar rumah sakit. Pada Standar Prosedur Operasional rumah sakit tempat dilakukannya penelitian, pasien dengan SC dinyatakan mengalami perpanjangan LOS apabila waktu perawatan $>4$ hari. Perancu ditetapkan berdasarkan penyakit penyerta yang dijumpai pada subjek yang diambil sebagai sampel. Terdapat 3 variabel perancu, yaitu diabetes melitus, preeklamsia, dan Ketuban Pecah Dini (KPD).

Etik penelitian telah mendapatkan persetujuan dari komisi etik penelitian kesehatan Universitas Pembangunan Nasional Veteran Jakarta dengan nomor Ethical Approval
B/2427III/2020/KEPK.

\section{HASIL}

Tabel 1. Ditribusi karakteristik subjek (n=98)

\begin{tabular}{|c|c|c|c|c|}
\hline & \multicolumn{2}{|c|}{ Lanjut AB } & \multicolumn{2}{|c|}{$\begin{array}{c}\text { Tidak Lanju } \\
\text { AB }\end{array}$} \\
\hline & n & $\%$ & n & $\%$ \\
\hline \multicolumn{5}{|l|}{ Umur } \\
\hline$<35$ tahun & 35 & 71.4 & 29 & 59.2 \\
\hline$>35$ tahun & 14 & 28.6 & 20 & 40.8 \\
\hline \multicolumn{5}{|c|}{ Kekerapan SC } \\
\hline $1 \mathrm{x}$ & 27 & 55.1 & 21 & 42.9 \\
\hline $2 \mathrm{x}$ & 15 & 30.6 & 21 & 42.9 \\
\hline $3 x$ & 6 & 12.3 & 6 & 12.2 \\
\hline $4 \mathrm{x}$ & 1 & 2.0 & 1 & 2.0 \\
\hline \multicolumn{5}{|c|}{ Usia Hamil* } \\
\hline 34 minggu & 0 & 0 & 1 & 2.0 \\
\hline 35 minggu & 1 & 2.0 & 0 & 0 \\
\hline 36 minggu & 2 & 4.0 & 1 & 2.0 \\
\hline 37 minggu & 3 & 6.1 & 7 & 14.3 \\
\hline 38 minggu & 31 & 63.4 & 7 & 14.3 \\
\hline 39 minggu & 9 & 18.4 & 27 & 55.2 \\
\hline 40 minggu & 3 & 6.1 & 6 & 12.2 \\
\hline \multicolumn{5}{|c|}{ Status Hamil* } \\
\hline G1P0A0 & 21 & 42.8 & 8 & 16.4 \\
\hline G2P0A1 & 2 & 4.0 & 3 & 6.0 \\
\hline $\mathrm{G} 2 \mathrm{P} 1 \mathrm{~A} 0$ & 12 & 24.8 & 18 & 36.8 \\
\hline G3P1A1 & 2 & 4.0 & 6 & 12.4 \\
\hline G3P2A0 & 8 & 16.4 & 7 & 14.4 \\
\hline G4P2A1 & 3 & 6.0 & 2 & 4.0 \\
\hline G4P1A2 & 0 & 0 & 3 & 6.0 \\
\hline G4P3A0 & 0 & 0 & 1 & 2.0 \\
\hline G5A3A1 & 0 & 0 & 1 & 2.0 \\
\hline G7P5A1 & 1 & 2.0 & 0 & 0 \\
\hline \multicolumn{5}{|c|}{ Variabel Perancu } \\
\hline \multicolumn{5}{|c|}{ Diabetes Melitus } \\
\hline $\mathrm{Ya}$ & 1 & 2.0 & 0 & 0 \\
\hline Tidak & 48 & 98.0 & 49 & 100 \\
\hline \multicolumn{5}{|c|}{ Preeklamsia } \\
\hline $\mathrm{Ya}$ & 0 & 0 & 1 & 2.0 \\
\hline Tidak & 49 & 100 & 48 & 98.0 \\
\hline \multicolumn{5}{|c|}{ Ketuban Pecah } \\
\hline $\begin{array}{l}\text { Dinl } \\
\text { Ya }\end{array}$ & 0 & 0 & 6 & 12.2 \\
\hline Tidak & 49 & 100 & 43 & 87.8 \\
\hline
\end{tabular}

*Status hamil: $\mathrm{G}=\mathrm{Gestasi} ; \mathrm{P}=$ Partus; $\mathrm{A}=$ Abortus

Jumlah data subjek yang diambil berdasarkan pada perhitungan sampel sebanyak 98 subjek, yaitu 49 subjek dengan terapi lanjutan antibiotik pascaoperasi SC dan 49 subjek tanpa terapi lanjutan pascaoperasi SC. Pada kelompok yang mendapatkan antibiotik lanjutan pascaoperasi SC, dari kategori umur subjek paling banyak dibawah 35 tahun, yaitu sebanyak 35 subjek (71.4\%) dan sebanyak 14 subjek (28.6\%) berusia diatas 35 tahun. Sementara pada kelompok yang tidak mendapat antibiotik lanjutan pascaoperasi SC, sebanyak 29 subjek (59.2\%) berusia di bawah 
Tabel 2. Analisa pengaruh pemberian antibiotik lanjutan pascaoperasi SC terhadap timbulnya tanda klinis IDO superfisial

\begin{tabular}{llcccccccc}
\hline & & \multicolumn{2}{c}{ Infeksi Daerah Operasi } & \multicolumn{3}{c}{ Unadjusted } & \multicolumn{3}{c}{ Adjusted } \\
& & Ya & Tidak & Nilai p & OR & IK95\% & Nilai p & OR & IK95\% \\
\hline $\begin{array}{l}\text { Antibiotik } \\
\text { pascaoperasi }\end{array}$ & Ya & $2(4.1)$ & $47(95.9)$ & 0.436 & 0.37 & $0.07-2.03$ & 0.098 & 0.157 & $0.02-1.41$ \\
SC & Tidak & $5(10.2)$ & $44(89.8)$ & & & & & & \\
\hline
\end{tabular}

35 tahun dan 20 (40.8\%) subjek berusia di atas 35 tahun. Mayoritas subjek dari kedua kelompok terhitung menjalankan SC untuk yang pertama kali, dengan usia kehamilan mayoritas 38 minggu (63.4\%) pada kelompok yang mendapatkan antibiotik pascaoperasi SC dan 39 minggu (55.2\%) pada kelompok yang tidak mendapatkan antibiotic pascaoperasi SC. Kelompok yang mendapatkan antibiotik lanjutan pascaoperasi SC didominasi oleh subjek dengan kelahiran anak pertama (42.8\%), sementara kelompok yang tidak mendapatkan antibiotik lanjutan pascaoperasi SC didominasi oleh subjek dengan kelahiran kedua (36.8\%).

Subjek dengan diabetes melitus pada kelompok yang diberikan antibiotik lanjutan pascaoperasi SC dijumpai sebanyak 1 subjek (2.0\%). Pada kelompok yang tidak diberikan antibiotik lanjutan pascaoperasi SC tidak dijumpai kasus Diabetes Melitus. Subjek dengan preeklamsia dijumpai sebanyak 1 subjek $(2.0 \%)$ pada kelompok yang tidak diberikan antibiotik lanjutan pascaoperasi SC. Disamping itu, juga dijumpai 6 subjek (12.2\%) yang dengan kasus Ketuban Pecah Dini (KPD) dari kelompok yang tidak diberikan antibiotik lanjutan pascaoperasi SC.

Sebelum mengontrol faktor perancu, pemberian antibiotik lanjutan pascaoperasi SC tidak secara bermakna memberikan pengaruh signifikan mengurangi kemungkinan timbulnya tanda klinis IDO $(\mathrm{OR}=0.37 ; \mathrm{p}=0.436 ; 0.07$ 2.03 IK 95\%). Setelah dilakukan pengontrolan terhadap variabel perancu, maka pemberian pemberian antibiotik lanjutan pascaoperasi SC juga tidak memiliki pengaruh signifikan mengurangi kemungkinan timbulnya tanda klinis IDO superfisial $(\mathrm{OR}=0.157 ; \mathrm{p}=0.098 ; 0.02-1.41$ IK95\%). Hasil analisis tersebut memperlihatkan bahwa pemberian antibiotik lanjutan pascaoperasi SC tidak mengurangi kemungkinan munculnya tanda klinis IDO superfisial.

Pada Tabel 3, satu model perubahan OR lebih kecil dari 10\%, sehingga dapat disimpulkan bahwa satu model di atas valid. Pada tabel di atas, model yang memiliki presisi terbaik adalah model dengan selisih interval kepercayaan paling sempit. Berdasarkan analisa tersebut, dapat disimpulkan bahwa model valid yang memiliki presisi terbaik adalah model 2 (A B C) dengan nilai presisi

Tabel 3. Analisa multivariat untuk mengontrol faktor perancu terhadap timbulnya tanda klinis IDO superfisial

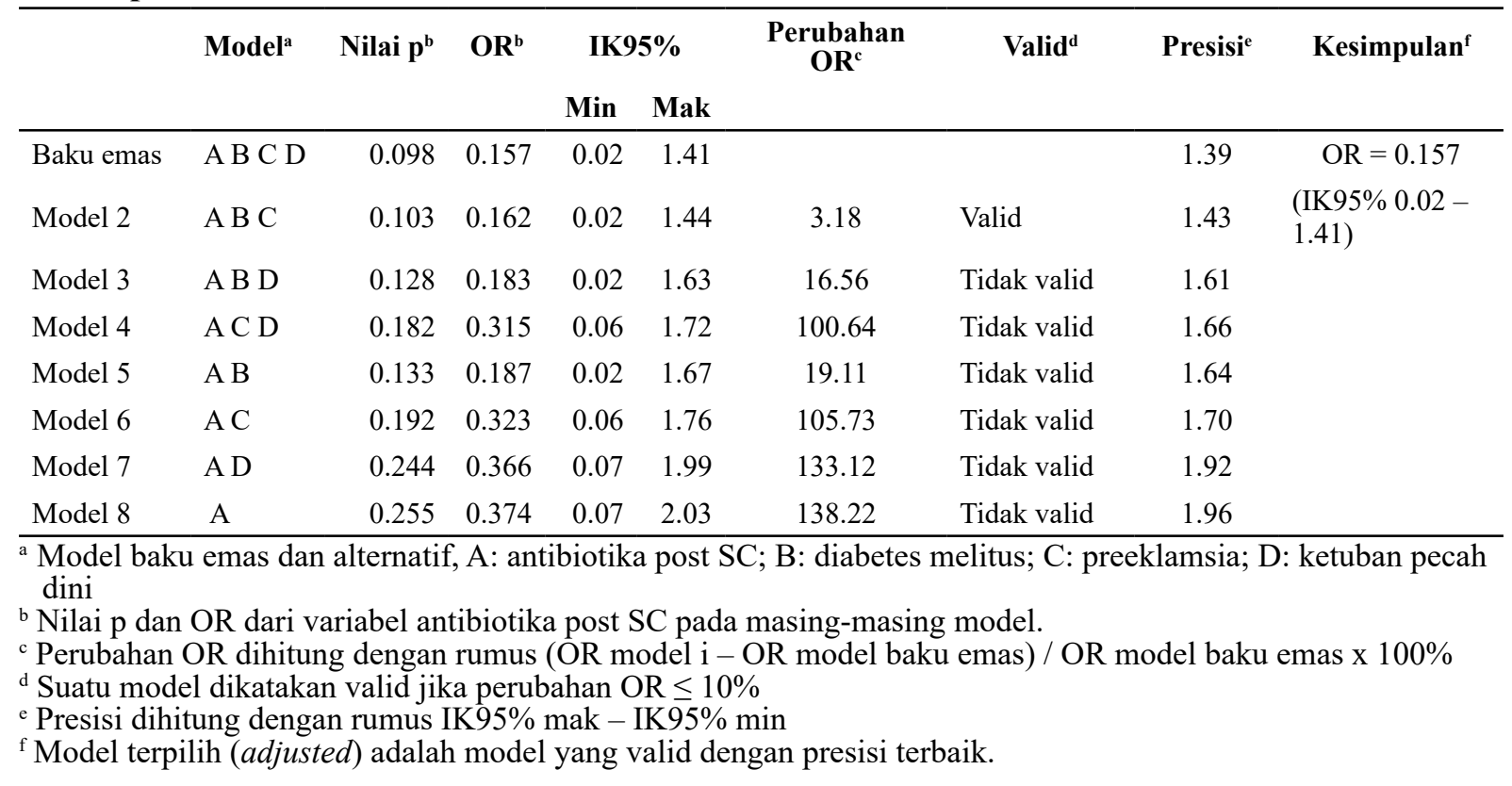


Tabel 4. Analisa pengaruh pemberian antibiotik lanjutan pascaoperasi SC terhadap LOS setelah mengontrol faktor perancu

\begin{tabular}{llllllllll}
\hline & & \multicolumn{2}{c}{ Lama Perawatan } & \multicolumn{2}{c}{ Unadjusted } & \multicolumn{3}{c}{ Adjusted } \\
& & $<\mathbf{4}$ hari & $>\mathbf{4}$ hari & Nilai p & OR & IK95\% & Nilai p & OR & IK95\% \\
\hline Antibiotika & Ya & $47(95.9)$ & $2(4.1)$ & 1.000 & 1.53 & $0.24-9.60$ & 0.561 & 1.73 & $0.27-10.85$ \\
pascaoperasi SC & Tidak & $46(93.9)$ & $3(6.1)$ & & & & & & \\
\hline
\end{tabular}

1.43, sehingga diabetes melitus dan preeklamsia merupakan variabel perancu yang dianggap dapat mempengaruhi tingginya angka tanda kejadian IDO superfisial.

Hasil analisis pada Tabel 4 menunjukkan bahwa pemberian antibiotik lanjutan pascaoperasi SC tidak memiliki pengaruh terhadap dengan LOS setelah mengontrol variabel perancunya $(\mathrm{OR}=1.73 ; \mathrm{p}=0.562 ; 0.27-10.85 \mathrm{IK} 95 \%)$.

Pada Tabel 5, perubahan OR lebih kecil dari $10 \%$, sehingga dapat disimpulkan bahwa 3 model di atas valid yaitu model 2 , model 4 , dan model 6. Pada tabel di atas, model yang memiliki presisi terbaik adalah model dengan selisih interval kepercayaan paling sempit. Berdasarkan analisa tersebut, dapat disimpulkan bahwa model valid yang memiliki presisi terbaik adalah model 2 (A B C) dengan nilai presisi 10.57, sehingga diabetes melitus dan preeklamsia merupakan variabel perancu yang dianggap dapat mempengaruhi tingginya angka LOS.

\section{PEMBAHASAN}

Setelah mengontrol faktor perancu, Pada penelitian ini dapat terlihat bahwa pemberian antibiotik lanjutan pascaoperasi SC tidak memberikan pengaruh signifikan terhadap penurunan kejadian IDO superfisial dan LOS. Seperti yang telah dijelaskan sebelumnya bahwa pada SC yang tergolong clean-contaminated, sebenarnya tidak diperlukan pemberian antibiotik lanjutan pascaoperasinya. Shamna MS et al menyatakan bahwa pemberian antibiotik profilaksis pada SC menurunkan risiko kejadian endometritis. ${ }^{(9)}$ Namun, pada penelitian-penelitian terdahulu, antibiotik profilaksis memang hanya diberikan satu kali sebelum operasi dan tidak diberikan secara berkelanjutan pascaoperasi.

Sampel yang diambil pada penelitian ini adalah sampel yang kesemuanya mendapatkan antibiotik profilaksis pada preoperasi SC dengan 3 kondisi patologis yang tercakup di dalamnya, yaitu diabetes melitus, preeklamsia, dan ketuban pecah dini. Pada kajian yang dilakukan oleh Novelia et al, Diabetes Melitus dikategorikan sebagai salah satu faktor intrinsik untuk terjadinya IDO, ${ }^{(10,11)}$ disamping faktor lain, seperti teknik operasi, pembersihan kulit, penggunaan drain, dan penggunaan antibiotik profilaksis tepat guna. ${ }^{(10,12)}$ Sementara itu, Younes et al pada kajiannya menyampaikan bahwa obesitas, ketuban pecah dini, tekanan darah tinggi, dan kelahiran prematur dapat menjadi faktor risiko kejadian IDO. ${ }^{(11)}$ Lijaemiro et al menyatakan bahwa usia ibu, usia kehamilan, dan lamanya operasi SC merupakan faktor yang juga berpengaruh terhadap kejadian IDO pada SC. ${ }^{(13)}$ Pada penelitian ini subjek yang diambil adalah semua subjek SC dengan teknik SC yang baku dan bundles IDO yang sesuai (termasuk teknik pembersihan kulit yang sesuai prosedur). Subjek yang terambil pada 2 kelompok dengan komorbid diabetes melitus, preeklamsia dan ketuban pecah dini. Tidak ada subjek terambil dengan penggunaan drain, obesitas atau kelahiran prematur. Oleh karena itu, dalam hal ini memang dibutuhkan penelitian dengan sampel yang lebih besar dengan cakupan komorbid lebih luas yang mungkin bisa berpengaruh terhadap kejadian IDO superfisial. Tetapi, dari penelitian-penelitian yang telah ada sebelumnya, memang belum ada penelitian yang menyatakan bahwa penggunaan antibiotik lanjutan pascaoperasi SC terbukti menurunkan risiko IDO superfisial, seperti halnya dinyatakan dalam penelitian ini.

Sebaliknya, pelaksanaan bundles IDO atau teknik baku perawatan preoperasi, intraoperasi sampai pascaoperasi, merupakan hal yang lebih diutamakan untuk dilakukan dalam rangka menekan kemungkinan terjadinya IDO pascaoperasi SC, ketimbang memberikan antibiotik lanjutan pascaoperasi SC.

Penelitian ini tidak membedakan jenis pemberian antibiotik profilaksis nya, melainkan hanya dilihat dampak dan pengaruh dari pemberian antibiotik lanjutan pada pasien-pasien SC yang sebelumnya (pada preoperasi) juga telah 
Tabel 5. Analisa multivariat untuk mengontrol faktor perancu terhadap LOS

\begin{tabular}{|c|c|c|c|c|c|c|c|c|c|}
\hline & \multirow[t]{2}{*}{ Model $^{\mathbf{a}}$} & \multirow[t]{2}{*}{ Nilai $\mathbf{p}^{\mathbf{b}}$} & \multirow[t]{2}{*}{$\mathbf{O R}^{\mathrm{b}}$} & \multicolumn{2}{|c|}{ IK95\% } & \multirow[t]{2}{*}{$\begin{array}{c}\text { Perubahan } \\
\text { OR }^{c}\end{array}$} & \multirow[t]{2}{*}{ Valid $^{\mathrm{d}}$} & \multirow[t]{2}{*}{ Presisi ${ }^{\mathrm{e}}$} & \multirow[t]{2}{*}{ Kesimpulan $^{\mathrm{f}}$} \\
\hline & & & & Min & Mak & & & & \\
\hline Baku emas & A B C D & 0.543 & 1.77 & 0.28 & 11.13 & - & - & 10.85 & $\mathrm{OR}=1.73$ \\
\hline Model 2 & A B C & 0.561 & 1.73 & 0.27 & 10.85 & -2.26 & Valid & 10.57 & $\begin{array}{l}\text { (IK95\% } 0.27- \\
10.85)\end{array}$ \\
\hline Model 3 & A B D & 0.648 & 1.53 & 0.24 & 9.61 & -13.56 & Tidak valid & 9.37 & \\
\hline Model 4 & A C D & 0.528 & 1.81 & 0.29 & 11.37 & 2.26 & Valid & 11.08 & \\
\hline Model 5 & A B & 0.665 & 1.50 & 0.24 & 9.40 & -15.25 & Tidak valid & 9.16 & \\
\hline Model 6 & $\mathrm{AC}$ & 0.546 & 1.76 & 0.28 & 11.08 & -0.56 & Valid & 10.80 & \\
\hline Model 7 & A D & 0.632 & 1.57 & 0.25 & 9.82 & -11.30 & Tidak valid & 9.57 & \\
\hline Model 8 & A & 0.648 & 1.53 & 0.24 & 9.60 & -13.56 & Tidak valid & 9.36 & \\
\hline
\end{tabular}

${ }^{\text {a }}$ Model baku emas dan alternatif, A: antibiotika post SC; B: diabetes melitus; C: preeklamsia; D: ketuban pecah dini

${ }^{\mathrm{b}}$ Nilai $\mathrm{p}$ dan OR dari variabel antibiotika post SC pada masing-masing model.

${ }^{c}$ Perubahan OR dihitung dengan rumus (OR model i - OR model baku emas) / OR model baku emas x 100\%

${ }^{\mathrm{d}}$ Suatu model dikatakan valid jika perubahan $\mathrm{OR} \leq 10 \%$

${ }^{\mathrm{e}}$ Presisi dihitung dengan rumus IK95\% mak - IK95\% min

${ }^{\mathrm{f}}$ Model terpilih (adjusted) adalah model yang valid dengan presisi terbaik.

mendapatkan profilaksis antibiotik. Kejadian IDO pada penelitian ini lebih besar pada kelompok yang tidak mendapatkan antibiotik lanjutan pascaoperasi SC tetapi pada uji kemaknaan tidak didapatkan perbedaan yang bermakna kejadian IDO pada kedua kelompok. Penelitian ini juga belum mengkaji lebih lanjut komorbiditas apa yang lebih berperan meningkatkan kemungkinan munculnya tanda-tanda klinis IDO, disamping juga berbagai kemungkinan seperti usia ibu, usia kehamilan atau juga lamanya operasi sebagai faktor risiko kejaidan IDO pada SC. Namun, pada penelitian ini, sesuai dengan temuan komorbid dari populasi sampel yang diambil, diabetes melitus dan preeklamsia diketahui sebagai faktor perancu yang dapat mempengaruhi IDO superficial dan LOS.

Penelitian Rahmansyah A et al juga menunjukan bahwa pemberian antibiotik jangka panjangpascaoperasiSCjugatidaksecarabermakna menurunkan angka kejadian IDO. ${ }^{(14)}$ Sementara Butt et al menyebutkan bahwa penggunaan antibiotik berkepanjangan pascaoperasi yang tidak sesuai indikasi merupakan penggunaan yang tidak bijak. Pemberian antibiotik yang tidak diberikan pascaoperasi terbukti menurunkan durasi penggunaan antibiotik $(17 \% ; \mathrm{p}=0.003)$, menurunkan jumlah peresepan antibiotik $(9.1 \%$; $\mathrm{p}=0.014)$, menurunkan rerata pembelian antibiotik $(25 \% ; \mathrm{p}=0.03)$ dan bahkan juga menurunkan rerata lama tinggal di rumah sakit/LOS $(\mathrm{p}=0.023)$.
(15) Penggunaan antibiotik profilaksis secara bijak (tidak berkelanjutan pascaoperasi) pada operasi SC juga terbukti menekan angka pembelian antibiotik. ${ }^{(15,16)}$ Federspiel et al pada penelitiannya yang melibatkan sampel cukup besar mencatat bahwa sebagian besar pasien dengan SC (46.8\%) sebenarnya hanya membutuhkan 2 hari perawatan pascaoperasi SC. ${ }^{(17)} \mathrm{Hal}$ ini memiliki tendensi bahwa kemungkinan pemberian antibiotik lanjutan pascaoperasi SC di rumah sakit justru memperpanjang LOS akibat menunggu selesainya pemberian antibiotik intravena pascaoperasi $\mathrm{SC}$ di rumah sakit. ${ }^{(15)}$ Blumenfeld YJ et al mendapatkan beberapa faktor yang menjadi faktor risiko pemanjangan LOS pada pasien pascaoperasi SC, antara lain ileus (adjusted odds ratio $[\mathrm{aOR}]=$ 12.28; 95\% CI $=8.98-16.8$ ); endometritis (aOR $=10.45 ; 95 \% \mathrm{CI}=9.51-11.5)$, dan IDO $(\mathrm{aOR}=$ $5.49 ; 95 \%$ CI $=4.54-6.63){ }^{(18)}$ Sebaliknya berbagai penelitian justru menyatakan bahwa pemanjangan LOS menjadi salah satu faktor risiko kejadian IDO pacaoperasi SC..$^{(19,20)}$

\section{KESIMPULAN}

Tidak terdapat pengaruh dari pemberian antibiotika lanjutan terhadap tanda kejadian IDO dan LOS pada pasien post SC sebelum dan setelah mengontrol variabel perancu. Pemberian antibiotik lanjutan pascaoperasi SC merupakan pemberian antibiotik yang tidak bijak. 


\section{UCAPAN TERIMA KASIH}

Ucapan terima kasih kami sampaikan kepada pihak Magister Kefarmasian Universitas Pancasila, Fakultas Kedokteran Universitas Trisakti, Universitas Pembangunan Nasional Veteran Jakarta, dan Yayasan Pelita RASPRO Indonesia yang telah mendukung terlaksananya penelitian ini.

\section{KONFLIK KEPENTINGAN}

Semua peneliti dalam penelitian ini menyatakan tidak ada konflik kepentingan dalam penulisan artikel ini.

\section{REFERENSI}

1. Oktaviani F, Wahyuno D, Yuniarti E. Evaluasi Penggunaan Antibiotik Profilaksis Terhadap Kejadian Infeksi Luka Operasi Pada Operasi Sectio Caesarea [Internet]. J Manajemen dan Pelayanan Farmasi. 2015;5(4):255-258. Available from: https://jurnal.ugm.ac.id/jmpf/article/view/29449

2. Desiyana LS, Soemardi A, Radji M. Evaluasi Penggunaan Antibiotik Profilaksis di Ruang Bedah Rumah Sakit Kanker "Dharmais" Jakarta dan Hubungannya dengan Kejadian Infeksi Daerah Operasi [Internet]. Indones $\mathrm{J}$ Cancer [Internet]. 2008;2(4):126-131. Available from: https:// indonesianjournalofcancer.or.id/e-journal/index. php/ijoc/article/view/55

3. Muzayyanah B, Yulistiani Y, Hasmono D, et al. Analysis of Prophylactic Antibiotics Usage in Caesarean Section Delivery. Folia Medica Indones. 2018;54(3):161-166. doi: 10.20473/fmi. v54i3.10004

4. Natadidjaja RI, Widodo D, Ariyani A, et al. Survei Persepsi Kebutuhan dan Hambatan Rumah Sakit dalam Menjalankan Fungsi Panitia Pengendalian Resistensi Antibiotik. J Hosp Accredit. 2019;1(2):36-40. doi: 10.35727/jha.v1i2

5. Dlamini LD, Sekikubo M, Tumukunde J, et al. Antibiotic prophylaxis for caesarean section at a Ugandan hospital: A randomised clinical trial evaluating the effect of administration time on the incidence of postoperative infections. BMC Pregnancy Childbirth. 2015;15(1):1-7. doi: 10.1186/s12884-015-0514-3

6. Enzler MJ, Berbari E, Osmon DR. Antimicrobial prophylaxis in adults. Mayo Clin Proc. 2011;86(7):686-701. doi: 10.4065/mcp.2011.0012

7. Horan TC, Andrus M, Dudeck MA. CDC/NHSN surveillance definition of health care-associated infection and criteria for specific types of infections in the acute care setting. Am J Infect Control. 2008;36(5):309-32. doi: 10.1016/j. ajic.2008.03.002

8. Rose A, Fekad B, Moore J, et al. Post-caesarean section surgical site infections: A retrospective audit and case note review at an Ethiopian referral hospital. Obstet Gynecol Reports. 2018;2(2):1-6. doi: 10.15761/ogr.1000126

9. Shamna MS, Kalaichelvan VK, Marickar YMF, et al. Cesarean Section and Prophylactic Antibiotics. IOSR J Pharm Biol Sci. 2014;9(2):51-4. doi:
10.9790/3008-09235154

10. Novelia S, Sia WS, Songwathana P. Surgical Site Infection among Women Post Cesarean Section: An Integrative Review. Nurse Media J Nurs. 2017;7(1):46-55. doi: 10.14710/nmjn.v7i1.15127

11. Younes RN, Farias TF, Sardenberg RAS. Surgical Site Infection in Cesarean Section Operation: Risk and Management. Int J Infect Prev. 2019;1(1):1624. doi: 10.14302/issn.2690-4837.ijip-19-2842

12. Zuarez-Easton S, Zafran N, Garmi G, et al. Postcesarean wound infection: Prevalence, impact, prevention, and management challenges. Int J Womens Health. 2017;9:81-88. doi: 10.2147/ IJWH.S98876

13. Lijaemiro H, Berhe Lemlem S, Tesfaye Deressa J. Incidence of Surgical Site Infection and Factors Associated among Cesarean Deliveries in Selected Government Hospitals in Addis Ababa, Ethiopia, 2019. Obstet Gynecol Int. 2020;2020:1-8. doi: $10.1155 / 2020 / 9714640$

14. Rahmansyah A, Hakimi M, Siswishanto R. Perbandingan Antara Pemberian Antibiotika Profilaksis Pada Seksio Sesar Sesuai Alur Klinis Rsup Dr Sardjito Dengan Antibiotika Dosis Multipel Terhadap Kejadian Infeksi Luka Operasi. J Kesehat Reproduksi. 2016;3(2):75-83. doi: 10.22146/jkr.35444

15. Butt SZ, Ahmad M, Saeed H, et al. Post-surgical antibiotic prophylaxis: Impact of pharmacist's educational intervention on appropriate use of antibiotics. J Infect Public Health. 2019;12(6):854 60. doi: 10.1016/j.jiph.2019.05.015

16. Fonseca SNS, Sofia $\mathrm{MH}$, Quintana $\mathrm{S}$, et al. Successful control program to implement the appropriate antibiotic prophylaxis for cesarean section. Rev Inst Med Trop Sao Paulo. 2008;50(2):79-82. doi: 10.1590/S003646652008000200003

17. Federspiel JJ, Suresh SC, Darwin KC, et al. Hospitalization Duration following Uncomplicated Cesarean Delivery: Predictors, Facility Variation, and Outcomes. AJP Rep. 2020;10(2):e187-e197. doi: $10.1055 / \mathrm{s}-0040-1709681$

18. Blumenfeld YJ, El-Sayed YY, Lyell DJ, et al. Risk Factors for Prolonged Postpartum Length of Stay Following Cesarean Delivery. Am J Perinatol. 2015;32(9):825-32. doi: 10.1055/s-0034-1543953

19. Haq A, Abdullah A, Akhtar S. Analysis of risk factors in surgical site infection following caesarean section. Int $\mathrm{J}$ Reprod Contraception, Obstet Gynecol. 2016;5(12):4256-62. doi: 10.18203/2320-1770.ijrcog20164323

20. Jasim HH, Sulaiman SAS, Khan AH, et al. Incidence and risk factors of surgical site infection among patients undergoing cesarean section. Clin Med Insights Ther. 2017;9:1-7. doi: $10.1177 / 1179559 \times 17725273$. 